\title{
Lymphocytotoxins in rheumatoid arthritis: prevalence, lymphocyte specificity, and HLA-DR antigens
}

\author{
P. H. WOOLEY, ${ }^{1}$ G. S. PANAYI, ${ }^{1}$ AND J. R. BATCHELOR ${ }^{2}$
}

From the ${ }^{1}$ Department of Medicine and Rheumatology, Guy's Hospital Medical School, London SEI 9RT, and the ${ }^{2}$ Department of Tissue Immunology, Royal Postgraduate Medical School, Hammersmith Hospital, London W12 OHS

SUMMARY $37 \%(57 / 155)$ of sera from patients with rheumatoid arthritis contain cold-reacting lymphocytotoxic antibodies. Lymphocytotoxins were predominantly of the weakly reactive type and were more likely to be present in patients who were HLA-DR4 positive. By contrast, patients who were HLA-DR3 positive were more likely to have strongly reactive lymphocytotoxins. The lymphocyte subclass reactivity of the lymphocytotoxins was: $67 \%$ versus B lymphocytes, $27 \%$ against both $\mathrm{T}$ and $\mathrm{B}$ cells, and $7 \%$ for $\mathrm{T}$ cells.

Lymphocytotoxins are antibodies which bind on to the surfaces of lymphocytes and in the presence of complement cause cell lysis. Lymphocytotoxins (LCA) may be either IgM or IgG immunoglobulins; the former are cold reacting (optimum $15-17^{\circ} \mathrm{C}$ ) while the latter are warm reacting (optimum $\left.37^{\circ}\right) .^{1}$ LCAs are found in the serum of normal individuals following a variety of bacterial or viral infections and after vaccination and immunisation. ${ }^{2}$ They are found also in many inflammatory and autoimmune diseases, including systemic lupus erythematosus (SLE) and rheumatoid arthritis (RA). ${ }^{3}$ LCAs in juvenile chronic arthritis and SLE have been considered as possible candidates in the development of some of the disturbed immune function seen in these diseases, since they may inactivate or kill suppressor $\mathrm{T}$ cells and $\mathrm{T}$ cells responding to mitogens. ${ }^{4} 5$

In rheumatoid arthritis (RA) some $35-50 \%$ of patients may have LCAs in their serum. ${ }^{36}$ The lymphocyte specificity of the LCA, HLA status of the patients and the functional consequences of the presence of LCA have not been studied in this disease. This study reports on the prevalence of LCAs, their lymphocyte specificity, and HLA DR status of 155 patients with RA.

\section{Patients and methods}

Patients. 155 patients with classical or definite RA according to the American Rheumatism Association

Accepted for publication 9 May 1980

Correspondence to Dr G. S. Panayi. criteria ${ }^{7}$ were tested for the presence of lymphocytotoxic antibodies. Serum samples were obtained at the time of tissue typing during previous genetic studies ${ }^{89}$ and stored at $-70^{\circ} \mathrm{C}$.

Normal panel. The lymphocytes from normal donors were used for the detection of lymphocytotoxins. Heparinised blood from laboratory staff or patients with back pain was obtained fresh, and lymphocytes separated by the method of Böyum. ${ }^{8}$ In testing for LCAs the panel of donor lymphocytes varied from 14 to 28 individuals.

Tissue typing. Patients were tissue typed as described previously ${ }^{8}{ }^{9}$ for HLA, A, B, C, and DR locus antigens.

Detection of lymphocytotoxins. Lymphocytotoxins in the 155 RA sera were tested for on the lymphocytes from the normal donors by the standard microdroplet National Institutes of Health cytotoxicity test carried out at room temperature. The lymphocyte specificity of 74 of these sera was also investigated with separated $\mathrm{T}$ and $\mathrm{B}$ lymphocytes, prepared as described previously, ${ }^{9}$ in a similar microcytotoxicity test.

The percentage of cells killed by a test serum (strength of killing) was estimated to the nearest $5 \%$ above background cell death and grouped into the following categories: negative $0 ;+20-35 \%$ death; $++40-45 \%$ death $;+++60-75 \%$ death $;++++$ $80-95 \%$ death. The frequency of cytotoxicity reactions against the panel of typing cells was also assessed as follows: negative $0 ;+<25 \%$; ++ $25-50 \%$; $+++50-75 \%$; $++++75-100 \%$. 


\section{Results}

\section{PREVALENCE OF LYMPHOCYTOTOXINS}

$37 \%(57 / 155)$ of RA sera showed cytotoxicity against the lymphocytes of 2 or more members of the panel of normal donors (Table 1). When the results of prevalence were analysed according to the HLA DR phenotype of the patients contributing the serum, it was found that patients who were HLA DR4 had a significantly higher prevalence $\left(\chi^{2}=9 \cdot 67\right.$; $P<0.005)$ of LCAs in their serum. LCAs were predominantly of the weakly reactive type, 43 $(75 \%)$ being of this nature.

\section{FREQUENCY AND STRENGTH OF REACTIVITY}

Table 2 shows the relationship between the number of lymphocytes of the panel killed by a particular serum (frequency) and the strength of killing. It can be seen that those sera which showed strong cytotoxicity also reacted with more members of the lymphocyte panel $\left(\chi^{2}=20.4 ; P<0.001\right)$. Having shown this relationship we then analysed strength of reactivity against the HLA DR antigen status of the serum donor. The relationship found was that between HLA DR3 and the presence of strongly reactive LCAs (Table $3(a), \chi^{2}=5 \cdot 77, P<0.025$ ), and HLA DR4 with the presence of weakly reactive LCAs (Table $3(b), \chi^{2}=5 \cdot 00, P<0 \cdot 025$ ).

Table 1 The occurrence of lymphocytotoxins in the serum of 155 patients and the $D R$ antigen phenotypes of the serum donors. There is a significant association between the presence of lymphocytotoxins and the presence of the DR4 haplotype

\begin{tabular}{|c|c|c|c|c|c|}
\hline \multirow[t]{2}{*}{$D R$} & \multicolumn{4}{|c|}{ Lymphocytotoxins } & \multirow[t]{2}{*}{$x^{2}$} \\
\hline & \multicolumn{2}{|c|}{ Positive (57) } & \multicolumn{2}{|c|}{ Negative (98) } & \\
\hline $\begin{array}{l}1 \\
2 \\
3 \\
4\end{array}$ & $\begin{array}{r}13 \\
7 \\
16 \\
43\end{array}$ & $\begin{array}{l}23 \\
12 \\
28 \\
75\end{array}$ & $\begin{array}{r}9 \\
15 \\
29 \\
49\end{array}$ & $\begin{array}{r}9 \\
15 \\
30 \\
50\end{array}$ & $\begin{array}{l}\text { NS } \\
\text { NS } \\
\text { NS } \\
9.67 \\
P<0.005\end{array}$ \\
\hline $\begin{array}{l}5 \\
6 \\
7 \\
\text { Blank }\end{array}$ & $\begin{array}{r}3 \\
4 \\
7 \\
21\end{array}$ & $\begin{array}{r}5 \\
7 \\
12 \\
37\end{array}$ & $\begin{array}{r}6 \\
9 \\
26 \\
53\end{array}$ & $\begin{array}{r}6 \\
9 \\
26 \\
54\end{array}$ & $\begin{array}{l}\text { NS } \\
\text { NS } \\
\text { NS } \\
\text { NS }\end{array}$ \\
\hline
\end{tabular}

NS $=$ not significant.

Table 2 Association in $R A$ sera between strength of $L C A$ and the frequency of positive reaction against cells of test panel. Sera with strong LCA react with significantly more cells

\begin{tabular}{lll}
\hline Frequency of killing & \multicolumn{2}{l}{ Strength of killing } \\
\cline { 2 - 3 } & $+/++$ & $+++I++++$ \\
\hline$<50 \%$ & 41 & 5 \\
$>50 \%$ & 2 & 9 \\
\hline
\end{tabular}

Table 3 The relationship between the strength of lymphocytotoxicity of sera with respect to the $H L A$ antigen of the patient. (a) Strongly cytotoxic sera occur most frequently in patients with $H L A-D R 3 .\left(\chi^{2}=5 \cdot 77\right.$, $P<0 \cdot 025$ ). (b) Weakly cytotoxic sera occur most frequently in patients with $H L A-D R 4 .\left(\chi^{2}=5 \cdot 00\right.$, $P<0.025)$

\begin{tabular}{llllc}
\hline & \multirow{2}{*}{$\begin{array}{l}\text { HLA } \\
\text { antigen }\end{array}$} & & \multicolumn{2}{c}{ Lymphocytotoxins } \\
\cline { 3 - 4 } & & & Strong & Weak \\
\hline (a) & DR3 & + & 9 & 7 \\
& & - & 8 & 33 \\
(b) & DR4 & + & 9 & 34 \\
& & - & 8 & 6 \\
\hline
\end{tabular}

Table 4 Reaction pattern of LCAs in 45 sera when tested against separated human $B$ and $T$ lymphocytes

\begin{tabular}{lcl}
\hline Lymphocyte specificity of lymphocytotoxins & \\
\cline { 1 - 3 } Lymphocyte class & $\begin{array}{l}\text { Number of sera } \\
(\text { per cent })\end{array}$ & $\begin{array}{l}\text { Strength of } \\
\text { cytotoxicity }\end{array}$ \\
\hline $\mathrm{T}$ & $3(7)$ & High \\
$\mathrm{B}$ & $30(67)$ & Low \\
$\mathrm{T}+\mathrm{B}$ & $12(27)$ & High \\
\hline
\end{tabular}

\section{SPECIFICITY OF LYMPHOCYTOTOXINS}

In a separate series 74 of these RA sera were screened against separated $\mathrm{T}$ and $\mathrm{B}$ lymphocytes from 12 normal panel members (Table 4). Twenty-nine sera did not have LCAs. Of the 45 sera with LCAs 30 $(67 \%)$ showed cytotoxic activity specific for B cells, 3 sera $(7 \%)$ were $\mathrm{T}$ cell specific, and 12 sera $(27 \%)$ reacted equally against $\mathrm{T}$ and $\mathrm{B}$ cells. The overall frequency of lymphocytotoxins when sera were tested against separated cells was $61 \%$ and contrasted with the frequency of LCAs against unseparated cells of $46 \%$. Performing the lymphocytotoxic assay on unseparated cells led to an underestimation of B lymphocyte specific LCAs, since $43 \%$ of sera with $B$ cell specificity were detected only after using separated lymphocytes.

\section{Discussion}

In this study we have examined the frequency, strength, and specificity of lymphocytotoxic antibodies in RA. LCAs detectable by reactions against whole lymphocyte preparations were seen in $37 \%$ of RA sera. Highly cytotoxic sera reacted with a high frequency in the panel, while weak sera showed a low frequency. The latter group were the most frequent LCAs described in this study. Overall, the presence of LCAs in RA was significantly associated with HLA DR4, but it was of interest to note that 
the strong/high frequency sera occurred in patients who were predominantly HLA DR3, while weak/ low frequency sera were associated with DR4.

The results of LCA reactions against $B$ and $T$ cells indicate that the majority of sera in RA have higher reactivity with $\mathrm{B}$ lymphocytes. The increased detection of LCAs in RA with separated cells does indicate, however, that a large number of $B$ specific sera are not detected by the cytotoxic test against whole lymphocytes.

These findings are in agreement with the description of LCAs in RA by Terasaki et al. ${ }^{3}$ with weak cytotoxic reactions in $57 \%$ of RA sera. The frequency of occurrence of LCAs in RA varies in the literature from 14 to $57 \%{ }^{3}{ }^{31011}$ This variation probably reflects the 'weakness' of the cytotoxicity of RA sera and minor differences in methodology. Research has concentrated on LCAs in systemic lupus erythematosus, which are more readily demonstrable, and occur in the majority of patients. Studies in other diseases have investigated lymphocyte specificities of LCA. Thus LCAs in lupus are thought to be $T$ cell specific. However, the only published evidence of an HLA association with LCAs is in myasthenia gravis, where there is a weak association with DR3. ${ }^{12}$

The association of LCAs with HLA DR4 described in this study is remarkable, considering the high overall frequency of DR4 in the RA patients $(59 \%)$. In view of the association of HLA DR4 with both RA itself and the occurrence of LCAs in the disease, it is particularly relevant to investigate LCAs in RA families. The role of these antibodies and their relationship to immune responsiveness and immunogenetic status may prove of particular importance in the rheumatic diseases.

This study was financed by a project grant from the Arthritis and Rheumatism Council.

\section{References}

1 Ozturk G, Terasaki P I. Non-HLA lymphocyte cytotoxins in various diseases. Tissue Antigens 1979; 14: 52-8.

2 Kreisler M J, Hirata A A, Terasaki P I. Cytotoxins in disease. II Antibodies against lymphocytes produced by vaccination. Transplantation 1970; 10: 411-5.

3 Terasaki P I, Mottironi V D, Barnett E V. Cytotoxins in disease. Autocytotoxins in disease. $N$ Engl J Med 1970; 283: 724-8.

4 Strelkauskas A J, Callery R T, McDowell J, Borel Y, Schlossman S F. Direct evidence for loss of human suppressor cells during active auto-immune disease. Proc Natl Acad Sci USA 1978; 75: 5150-4.

5 Kaike T, Kobayashi S, Yoshiki T, Itoh T, Shirai T. Differential sensitivity of functional subsets of $T$ cells to the cytotoxicity of natural T-lymphocytotoxic autoantibody of systemic lupus erythematosus. Arthritis Rheum 1979; 22: 123-9.

6 Steffen C, Thumb N, Frank O, Eberl R, Tausch G, Boros M. Demonstration of lymphocytotoxins in rheumatoid arthritis in comparison with clinical course and other antibody activities. $Z$ Immunitaetsforsch Immunobiol 1973; 145: 303-11.

7 Ropes M W, Bennet G A, Cobb S, et al. Diagnostic criteria for rheumatoid arthritis. Ann Rheum Dis 1959; 18: 49-53.

8 Panayi G S, Wooley P, Batchelor J R. Genetic basis of rheumatoid disease: HLA antigens, disease manifestations and toxic reactions to drugs. $\mathrm{Br} M e d \mathrm{~J} 1978$; ii: 1326-8.

9 Wooley P H, Griffin J, Panayi G S, Batchelor J R, Welsh K I, Gibson T J. HLA-DR antigens and toxicity to sodium aurothiomalate and D-penicillamine in rheumatoid arthritis. $N$ Engl $J$ Med in press.

10 Mittal K, Rossen R, Sharp T, Lidsky M, Butler W T. Lymphocyte cytotoxin antibodies in systemic lupus erythematosis. Nature 1970: 225 : 1255-6.

11 Browning J D, Dick H M, El-Ghobarey A, Dick W C. Levamisole, rheumatoid arthritis, and cold lymphocytotoxic antibodies. Lancet 1977 ; i: 820.

12 Zilko P J, Dawkins R L, Holmes K, Witt C. Genetic control of suppressor lymphocyte function in myasthenia gravis: relationship of impaired suppressor function to HLA-B8 DRw3 and cold reactive lymphocytotoxic antibodies. Clin Immunol Immunopathol 1979; 14: 222-30. 